\title{
THE EFFECT OF SEWAGE SLUDGE ON AND CUP PLANT'S (SILPHIUM PERFOLIATUM L.) BIOMASS PRODUCTIVITY UNDER WESTERN LITHUANIA'S RETISOL
}

Gintaras ŠIAUDINIS, Vèžaičiai Branch of the Lithuanian Research Centre for Agriculture and Forestry, Gargždų 27-6, LT-96216, Vėžaičiai, Klaipėdos raj., Lithuania, gintaras.siaudinis@ vezaiciai.lzi.lt (corresponding author)

Danutė KARČAUSKIENĖ, Vèžaičiai Branch of the Lithuanian Research Centre for Agriculture and Forestry, Gargždų 27-6, LT96216, Vėžaičiai, Klaipėdos raj., Lithuania, danute.karcauskiene@vezaiciai.lzi.lt

The long-term field experiment with new high yielding perennial energy crop - cup plant (Silphium perfoliatum L.) was conducted in order to evaluate its biomass productivity in Vėžaičiai branch of the Lithuanian Research Centre for Agricultural and Forestry. Experimental site -

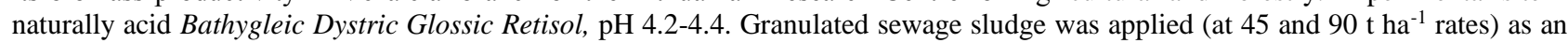
alternative organic fertilizer. The fertilization was done at the beginning of the experiment, prior to cup plant's sprouts planting in 2013. Each experimental year, traditional $\mathrm{N}_{60} \mathrm{P}_{60} \mathrm{~K}_{60}$ fertilization was performed in a separate treatment. Cup plant's biomass was harvesting once per season at the end of vegetation.

Cup plant's dry mass (DM) yield substantially increased from $2.80 \mathrm{t} \mathrm{ha}^{-1}$ (in 2014) to $13.41 \mathrm{t} \mathrm{ha}^{-1}$ (in 2016 ). The use of sewage sludge fertilization was notably superior to that of mineral fertilization for cup plant's biomass productivity. In all experimental years, the optimal was the application of $45 \mathrm{t} \mathrm{ha}^{-1}$ rate of sewage sludge - in compare with unfertilized treatment (control), DM yield increased by $66 \%$, on average. Increasing of sewage sludge rate up to $90 \mathrm{~kg} \mathrm{ha}^{-1}$ did not give any DM yield supplement. Energy evaluation of growing technology revealed that the application of $45 \mathrm{t} \mathrm{ha}^{-1}$ sewage sludge rate caused the substantial increase of energy output from 1 ha; and on the contrarily, sharply decreased net energy ratio.

In order to determine the long-term effects of fertilization on biomass yield, these studies will continue a few more years.

Keywords: cup plant, DM yield, energy evaluation, NPK, sewage sludge

\section{INTRODUCTION}

Sewage sludge is a byproduct of sewage treatment processes (). It is rich in organic and inorganic plant nutrients and might be a substitute for traditional mineral fertilizers. Sewage sludge affects soil physico-chemical and biological properties. (McGrath et al., 2001; Singh, Agrawal, 2008). Sewage sludge as organic matter is rich in nitrogen and phosphorus. As well, it significantly increase many agricultural crops productivity (Hortenstine, Rothwell, 1973; Tsakou et al., 2003; Singh, Agrawal, 2008). The biggest disadvantage of sewage sludge is the availability of many heavy metals, which often restricts its uses (Singh, Agrawal, 2008).

Another interesting and important research objects are energy crops. The cultivation of energy crops slowly but steadily increases in many countries around the World. In general, the most important characteristics for energy crops are their high yielding, low energy input and low production cost, least contaminants and low nutrient requirements. In addition to that, energy crops should be well adapted to local weather and soil conditions (McKendry, 2003).

In recent years, in Lithuania particular attention has been paid to the local and introduced perennial plant species with high biomass productivity and high-energy value. The focus of investigations is targeted to high yielding shortrotation coppices (particularly willows) (Bakšienė et al., 2012), introduced coarse stemmed crops (cup plant, miscanthus) () and perennial grasses (Jasinskas, Kryževičienė, 2006; Jasinskas et al., 2008). (;).

Out of introduced species, some Silphium species are characterized as high yielding crops. As such, Silphium species were investigated as potential fodder and energy crops in some Countries Worldwide (Kowalski, 2004; Kowalski, 2007; Lehmkuhler et al., 2007; Mast et al., 2014; Gansberger et al., 2015; Haag et al., 2015). Since the growing technology is not elaborated sufficiently, cup plant is still not widely cultivated (Gansberger et al., 2015).

As we mentioned, it is important to raise high biomass yield with relatively low inputs. As concerning fertilization, some experiments with organic and mineral were done in order to evaluate fertilization effect on cup plant's biomass yield. It was estimated that the combination of the organic (liquid digestate from a biogas plant) and mineral fertilization gave the highest biomass yield (Vetter et al., 2010). According to Klimont et al., 2015, the fertilization with sewage sediment positively influenced organic matter content and soil $\mathrm{pH}$ reduction (Klimont et al., 2015).

Copyright (C) 2017 The Authors. Published by Aleksandras Stulginskis University. This is an open-access article distributed under the terms of the Creative Commons Attribution License (CC-BY 4.0), which permits unrestricted use, distribution, and reproduction in any medium, provided the original author and source are credited. 
For example, naturally acid Albeluvisols and Fluvisols are prevailing in Western Lithuania region. Without maintenance liming, soils return to their original state which leads to the deterioration of their physical, chemical and microbial properties (Mažvila et al., 2004). With increasing demand for biomass for bioenergy industry, a significant proportion of such soils could be used for the cultivation of energy crops. There are few data concerning energy crops productivity under different soil $\mathrm{pH}$ levels.

In order to avoid competition with conventional plants, energy crop should be grown in the areas that are less favorable for traditional agriculture, particularly in less fertile soils (Borkowska, Molas, 2012; Šiaudinis et al., 2015). In this respect, naturally acid Retisols and Luvisols are prevailing in Western Lithuania's region. Without liming, these soils return to their original state with worsens soil physical, chemical and microbial properties (Mažvila et al., 2004). Besides liming, a portion of such soils might be suitable for the cultivation of the energy crops, which are less susceptible to high soil acidity.

The current experiment had the aim to investigate the effect of granulated sewage sludge to cup plant's productivity and carry out an energy assessment of plant cultivation.

\section{MATERIALS AND METHODS}

The field experiments with cup plant (Silphium perfoliatum L.) was performed at Véžaičiai branch of the Lithuanian Research Centre for Agriculture and Forestry (Western Lithuania, 55 43' N, 21 ${ }^{\circ} 27^{\prime} \mathrm{E}$ ). The soil of the experimental site is naturally acid moraine loamy (Bathygleyic Dystric Glossic Retisol) (WRB, 2014), (clay ( $<0.002 \mathrm{~mm})$ $-15.0 \%), \mathrm{pH}_{\mathrm{KCl}}$ was $4.30-4.93$. The average amount of precipitation is 700-900 $\mathrm{mm}$ per year.

Cup plant sprouts were planted at the end of May in 2013. Each treatment was composed of two adjacent rows. The distance between plants in each row was $0.50 \mathrm{~m}$, the distance between two rows was $0.80 \mathrm{~m}$, and the distance between each treatment was $1.00 \mathrm{~m}$.

The experiment was composed of four treatments: 1) not fertilized (control treatment); 2) fertilized by $\mathrm{N}_{60} \mathrm{P}_{60} \mathrm{~K}_{60}$; 3) fertilized by $45 \mathrm{t} \mathrm{ha}^{-1}$ of sewage sludge; 4) fertilized by $90 \mathrm{t} \mathrm{ha}^{-1}$ of sewage sludge rate. Fertilization treatments with 3 replications were randomly allocated.

The granulated sewage sludge was applied once in 2014. The fertilization was done at the $3^{\text {rd }}$ decade in May. NPK fertilization (at $2^{\text {nd }}$ treatment) was performed each year before the beginning of crops vegetation.

Cup plant's stems harvesting started in 2014. Each year, at the end of September, the stems of cup plant was cut by rotary reaper. The total biomass yield was recalculated into air-dry mass (DM) yield.

By calculating the total energy expenses $\left(\mathrm{GJ} \mathrm{ha}^{-1}\right)$, we included the direct energy expenses (ploughing, cultivation, protection from weeds, biomass harvesting, and transportation), indirect energy expenses (share of energy in fertilisers and herbicides), machinery energy consumption, and human labour input.

The energy equivalents for the fertilizers used in the experiment: $47.1 \mathrm{MJ} \mathrm{kg}^{-1}$ for $\mathrm{N}, 15.8 \mathrm{MJ} \mathrm{kg}^{-1}$ for $\mathrm{P}_{2} \mathrm{O}_{5}$, and $9.3 \mathrm{MJ} \mathrm{kg}^{-1}$ for $\mathrm{K}_{2} \mathrm{O}$ and for sewage sludge after fermentation - $12 \mathrm{MJ} \mathrm{kg}^{-1}$.

Net energy ratio (or energy balance) (NER) was calculated by the equation (acc. to Shahin et al., 2008):

$\mathrm{NER}=$ energy output $\left(\mathrm{GJ} \mathrm{ha}^{-1}\right)$ - energy input $\left(\mathrm{GJ} \mathrm{ha}^{-1}\right)$

A two-way analysis of variance with three replications design was performed on the data of cultivation year and fertilization rate, using analysis of variance (ANOVA) to determine significance at 95\% probability level (Tarakanovas, Raudonius, 2003).

\section{RESULTS AND DISCUSSION}

Dry mass (DM) yield. Since the growing of plant cup's stems begins in the second growing year, the estimation of results started from 2014 season. DM yield results are presented in figures 1-3. The obtained results show that the productivity was quite low in the first harvestable season (in 2014). DM yield ranged from $2.20 \mathrm{t} \mathrm{ha}^{-1}$ (in control treatment). In the following two growing seasons, cup plant's productivity progressively increased from 3.74 to $6.83 \mathrm{t} \mathrm{ha}^{-1}$ (in 2015) and from 10,78 to 17,58 $\mathrm{t} \mathrm{ha}^{-1}$ (in 2016). In control treatment, plants did not receive any fertilization through all the experimental years. However, DM yield increased by 5 times per 3 successive growing years. Cup plant has a deep rooting system. Thus, by the development of root system, these the plants can take all necessary nutrients not only from upper but from deeper soil layers as well. Surprisingly, in compare with control treatment, the annual application by mineral fertilizers (N60P60K60) did not increase DM yield significantly. The results suggest that perhaps it necessary to perform mineral fertilization each growing year. The best results were obtained using sewage sludge. Each year (although not always significant at $95 \%$ probability level), the application of $45 \mathrm{t}$ ha-1 rate causes the highest cup plant's productivity. In this way, DM yield increased from $2.87 \mathrm{t} \mathrm{ha}^{-1}$ (in 2014) to $17.58 \mathrm{t} \mathrm{ha}^{-1}$ (in 2016) (yield increased by 5,3 times). It is interesting to note that the use of double sewage sludge rate $\left(90 \mathrm{t} \mathrm{ha}^{-1}\right)$ had no significant impact to DM yield. Even more, cup plant's productivity tended to decrease (although not significant at $95 \%$ rate). Thus, the excessive use of such organic fertilizer like sewage sludge had a tension to decrease annual biomass productivity.

Particularly, the cup plant's yield increased with increasing number of stems and the mass of those stems. These results will be presented in a new separate article later.

The parallel trials with cup plant in the same experimental site revealed that using the annual $\mathrm{N}_{0^{-}-60^{-120}} \mathrm{P}_{60} \mathrm{~K}_{60}$ fertilization rate revealed, that in dependence on growing season, cup plant productivity is ranging from 11,00 to 13,67 $\mathrm{t}$ ha $^{-1}$ DM (Šiaudinis et al., 2015). The results of field studies hold in other countries shows, that cup plant's productivity 
highly depends on growing conditions. Despite the fact, that cup plant is originating from Northern America, its DM yield in some USA regions is low and ranging from 2,00 to 6,80 $\mathrm{t} \mathrm{ha}^{-1}$ (Voigt et al., 2012; Assefa et al., 2015). Although the results obtained by Polish investigators reveals that different Silphium species could easily accumulate 17,80-28,80 $\mathrm{t} \mathrm{ha}^{-}$ ${ }^{1}$ DM per growing season (Kowalski 2004; Kowalski 2007). Then growing in Western Siberia (Russia), the average annual cup plant DM yield per 10 successive seasons was about 15,60 $\mathrm{t} \mathrm{ha}^{-1}$.

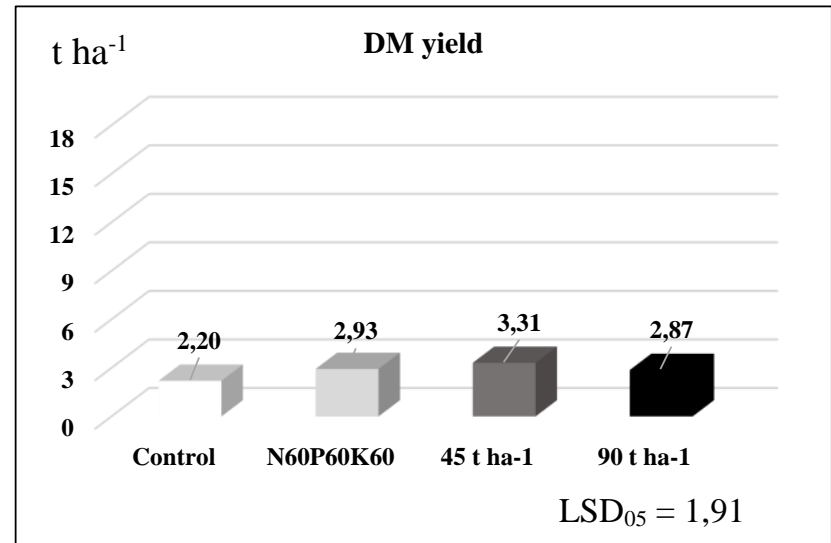

Figure 1. The dependence of cup plant DM yield $(\mathrm{t} \mathrm{ha-1)}$ on different fertilization in 2014

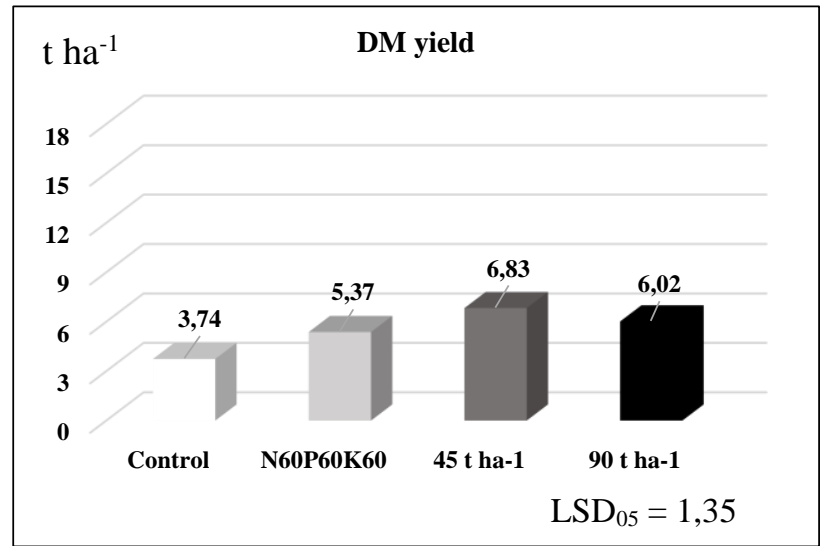

Figure 2. The dependence of cup plant DM yield $\left(\mathrm{t} \mathrm{ha}^{-1}\right)$ on different fertilization in 2015

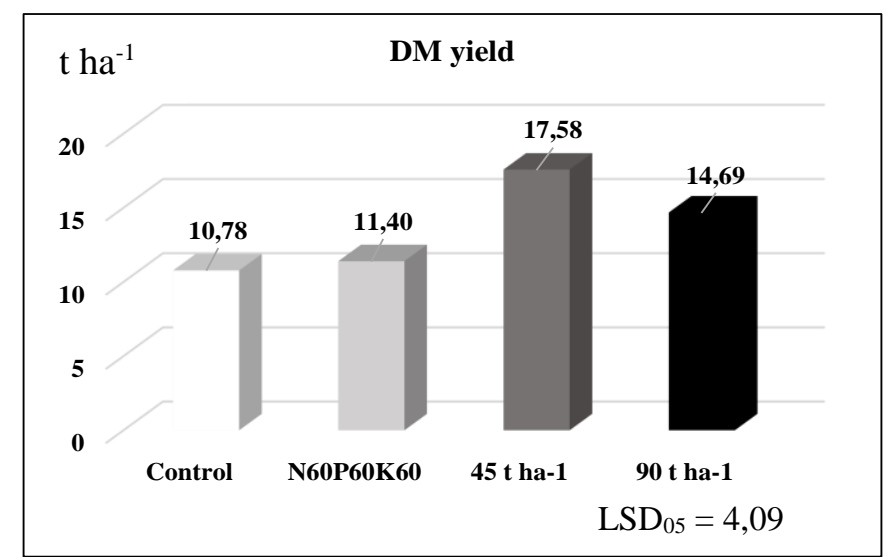

Figure 3. The dependence of cup plant DM yield $\left(\mathrm{t} \mathrm{ha}^{-1}\right)$ on different fertilization in 2016

Energetic evaluation. The data of the energy parameters are presented in Table 1. The direct expenses consist of such technological operations like autumnal ploughing, pre-sowing cultivation, distribution of fertilizers, sprout planting, plant protection, biomass harvesting and transportation. Indirect expenses consist of the energy amount bounded in pesticides and fertilizers. Out of them, the energy share of fertilizers is the highest. Except fertilization, all other operations were similar in all four treatments. In dependence on fertilization type, the total energy expenses (including direct and indirect expenses) varied from 11.00 to $1091 \mathrm{GJ} \mathrm{ha}^{-1}$. The amount of energy bounded in sewage sludge is quite huge. Thus, the intervals of energy expenses between treatments are enormous. After 3 growing years, cup plant accumulated from 276 to $457 \mathrm{GJ} \mathrm{ha}^{-1}$ of energy in their above-ground biomass. We can find that by applying sewage sludge, substantially higher amount of energy (or energy putput) is being accumulated in biomass. However, net energy ratio (NER) after 3 harvestable seasons was still negative. Yet, the experiment is long-term. In this respect, we hope that the impact of sewage sludge will be long lasting, while at the same time the energy value will increase significantly.

Table 1. Energetic evaluation of cup plant growing technology

\begin{tabular}{|l|c|c|c|}
\hline Treatments & $\begin{array}{c}\text { Total energy expenses for cultivation } \\
\text { GJ ha }\end{array}$ & $\begin{array}{c}\text { Energy output in biomass, } \\
\text { GJ ha }^{-1}\end{array}$ & $\begin{array}{c}\text { Net energy ratio } \\
\text { (NER) }\end{array}$ \\
\hline \multicolumn{4}{|c|}{ (per 3 successive growing years) } \\
\hline Control (not fertilized) & 11,00 & 276 & 265 \\
\hline N60P60K60 & 24,24 & 325 & 300 \\
\hline $45 \mathrm{t} \mathrm{ha}^{-1}$ rate & 551 & 457 & -94 \\
\hline $90 \mathrm{t} \mathrm{ha}^{-1}$ rate & 1091 & 389 & -702 \\
\hline
\end{tabular}

It is worth to note that as for today, sewage sludge as organic fertilizer is a cheap material. Contrarily, mineral fertilizers cost big money. Out of other positive factors, we found that sewage sludge enriches soil by mineral nutrients 
(particularly by nitrogen and phosphorus), reduce soil acidity and improves soil physical properties. These data will be published in a separate article.

Commonly, the positive NER balance is receivable due to photosynthetic active radiation, which inspires the accumulation of solar energy in plants. Other means, such as fertilisers, pesticides, soil cultivation, etc. only enable plants to accumulate a higher amount of energy in plants (Aleksynas, 1990).

\section{DISCUSSION}

Three experimental years revealed that the use of sewage sludge as a cheap organic fertilizer is an excellent solution, because it maintains high cup plant's biomass productivity for many years. Since the experiment is ongoing, we hope that the high biomass productivity will remain in the next few years without any additional fertilization. Due to high cost of mineral fertilization, annual NPK fertilization is not justified. Thus, by growing any energy crop, alternative source of fertilization is desirable. We can conclude that the application of $45 \mathrm{t} \mathrm{ha}^{-1}$ sewage sludge is sufficient for high annual cup plant biomass yield. Further increase of fertilization rate is unprofitable.

\section{REFERENCES}

1. Aleksynas A. 1990.Agroenergetika ir derlius (Agroenergetics and yield). LŽŪM, Vilnius, Lithuania, pp. 42. (in Lithuanian)

2. Assefa, T., Wu, J., Albrecht, K. A., Johnson, P. J., Boe, A. 2015. Genetic variation for biomass and related morphological traits in cup plant (Silphium perfoliatum L.). American Journal of Plant Sciences, Vol. 6, Iss. 8, pp. $1098-1108$. http://dx.doi.org/10.4236/ajps.2015.68114

3. Bakšienė, E., Titova, J., Nedzinskienė, T.L. 2012. Ivairių gluosnių (Salix L.) veislių auginimo kurui tyrimai. Žemès ūkio mokslai, Vol. 19, Iss. 2, pp. 90-97. (in Lithuanian) https://doi.org/10. 6001/zemesukiomokslai.v19i2.2332

4. Borkowska, H., Molas, R. 2012. Two extremely different crops, Salix and Sida, as sources of renewable bioenergy. Biomass and bioenergy, Vol. 36, pp. 234-240. https://doi.org/10.1016/ j.biombioe.2011.10.025

5. Gansberger, M., Montgomery, L.F, Liebhard, P. 2015. Botanical characteristics, crop management and potential of Silphium perfoliatum L. as a renewable resource for biogas production: A review. Industrial Crops and Products, Vol. 63, pp. 362-372. https://doi.org/10. 1016/j.indcrop.2014.09.047

6. Haag, N.L., Nägele, H.J., Reiss, K., Biertümpfel, A., Oechsner, H. 2015. Methane formation potential of cup plant (Silphium perfoliatum). Biomass and Bioenergy, Vol. 75, pp. 126-133. https://doi.org/10.1016/j.biombioe.2015.02.012

7. Hortenstine, C.C., Rothwell, D.F. 1973. Pelletized municipal refuse compost as a soil amendment and nutrient source for sorghum. Journal of environmental quality, Vol. 2, Iss. 3, pp. 343-345. https://doi.org/10.2134/jeq1973.00472425000200030007x

8. Jasinskas, A., Kryževičienè. R. 2006. Energetiniai žolynai ir jų auginimo bei ruošimo kurui sąnaudos. Žemės ūkio inžinerija, Vol.38, Iss. 3, pp. 59-71. (in Lithuanian)

9. Jasinskas, A., Zaltauskas, A., Kryzeviciene, A. 2008. The investigation of growing and using of tall perennial grasses as energy crops. Biomass and Bioenergy, Vol. 32, Iss. 11, pp. 981-987. https://doi.org/10.1016/j.biombioe.2008.01.025

10. Klimont, K., Bulińska-Radomska, Z., Górka, J., Osińska, A. 2015. Badanie przydatności rożnika przerośniętego (Silphium perfoliatum L.) do rekultywacji terenów po otworowej eksploatacji złóż siarki. Problemy Inżynierii Rolniczej, Vol. 23, Iss. 2, pp. 61-73 (in Polish)

11. Kowalski, R. 2004. Growth and development of Silphium integrifolium in the first 3 years of cultivation. New Zealand journal of crop and horticultural science, Vol. 32, Iss. 4, pp. 389-395. http://dx.doi.org/10.1080/01140671.2004.9514320

12. Kowalski, R. 2007. Silphium trifoliatum L.- a new alternative cultivation herbal plant? Acta Agriculturae Scandinavica Section BSoil and Plant Science, Vol. 57, Iss. 2, pp. 155-166. http://dx.doi.org/10.1080/09064710600766503

13. Lehmkuhler, J.W., Ramos, M.H., Albrecht, K.A. 2007. Cupplant silage as a replacement for corn silage in growing beef cattle diets. Forage and Grazinglands, Vol. 5, Iss. 1. https://doi:10.1094/FG-2007-1107-01-RS

14. Mast, B., Lemmer, A., Oechsner, H., Reinhardt-Hanisch, A., Claupein, W., Graeff-Hönninger, S. 2014. Methane yield potential of novel perennial biogas crops influenced by harvest date. Industrial Crops and Products, Vol. 58, pp. $194-203$. https://doi.org/10.1016/j.indcrop. 2014.04.017

15. Morera, M. T., Echeverria, J., Garrido, J. 2002. Bioavailability of heavy metals in soils amended with sewage sludge. Canadian journal of soil science, Vol. 82, Iss. 4, pp. 433-438. https://doi.org/10.4141/S01-072

16. McKendry, Peter. 2002. Energy production from biomass (part 1): overview of biomass. Bioresource technology, Vol. 83, Iss. 1, pp. 37-46. https://doi.org/10.1016/S0960-8524(01)00118-3

17. McGrath, S. P., Chaudri A.M., Giller K.E. 1995. Long-term effects of metals in sewage sludge on soils, microorganisms and plants. Journal of Industrial Microbiology \& Biotechnology, Vol. 14, Iss. 2, pp. 94 -104. http://doi: 10.1007/BF01569890

18. Singh, R. P., Agrawal, M. 2008. Potential benefits and risks of land application of sewage sludge. Waste management, Vol. 28, Iss. 2, pp. 347-358. https://doi.org/10.1016/ j.wasman.2006.12.010

19. Shahin S., Jafari A., Mobli H., Rafiee S., Karimi M. 2008. Effect of Farm Size on Energy Ratio for Wheat Production: A Case Study from Ardabil Province of Iran. American Eurasian Journal of Agricultural \& Environmental Science, Vol. 3, Iss. 4. pp. $604-608$.

20. Šiaudinis, G., Jasinskas, A., Šarauskis, E., Steponavičius, D., Karčauskienè, D., \& Liaudanskienè, I. 2015. The assessment of Virginia mallow (Sida hermaphrodita Rusby) and cup plant (Silphium perfoliatum L.) productivity, physico-mechanical properties and energy expenses. Energy, Vol. 93, pp. 606-612. https://doi.org/10.1016/j.energy.2015.09.065

21. Tsakou, A., Roulia, M., Christodoulakis, N.S. Growth parameters and heavy metal accumulation in poplar tree cultures (Populus euramericana) utilizing water and sludge from a sewage treatment plant. Bulletin of environmental contamination and toxicology, Vol. 71, Iss.2, pp. 0330-0337. https://doi.org/10.1007/s00128-003-0168-0 
22. Vetter, A., Conrad, M., Biertümpfel, A. 2010. Optimierung des Anbauverfahrens für Durchwachsende Silphie (Silphium perfolatium) als Koferment in Biogasanlagen sowie Überführung in die landwirtschaftliche Praxis-Abschlussbericht (Optimization of Cultivation Practice for Cup Plant (Silphium perfolatium) as Co-Ferment in Biogas Plants as well as the Transfer into Farming Practice). (in German)

23. Voigt, T.B., Lee, D.K., Kling, G.J. 2012. Perennial herbaceous crops with potential for biofuel production in the temperate regions of the USA. CAB Reviews, Vol. 7, Iss. 015, pp. 1-13. https://doi.10.1079/PAVSNNR20127015 